\title{
Aspects Affecting the Accountability Performance of Government Agencies Banyuasin District
}

\author{
Rita Martini1 ${ }^{1, *}$ Muhammad Aulia Ramadhan ${ }^{1}$ Sukmini Hartati ${ }^{1}$ \\ ${ }^{1}$ Accounting Department, Polytechnic State of Sriwijaya, Palembang 30139, Indonesia \\ *Corresponding author. Email: ritamartini@polsri.ac.id
}

\begin{abstract}
This study aims to work out the effect of the government's control system, the utilization of data technology, and therefore the competence of human resources on the performance accountability of state agencies in Banyuasin Regency. The population during this study was the Regional Apparatus Organization (OPD) of Banyuasin Regency, but only 19 of them were used as samples. The information collection technique used purposive sampling.This study uses multiple linear regression analysis tools with SPSS version 24. Supported the research results, it's known that the govt control system, the employment of data technology, and also the competence of human resources have a positive and significant effect on the performance accountability of presidency agencies. The simultaneous test shows that the variables of the govt control system, the employment of knowledge technology, and also the competence of human resources together have a control on the performance accountability of presidency agencies.
\end{abstract}

Keywords: Performance accountability, good government governance.

\section{INTRODUCTION}

Reform has changed various aspects of national and state life, one in all which is that the existence of regional autonomy and decentralized management of state finances. Regional governments are given the authority to manage their own regions supported on the prevailing regional autonomy principles. Within the aspect of accountability, government programs must be oriented towards the results, benefits or outputs and outcomes of those programs. Not only is that the budget spent then well reported but the positive impact is nonexistent. Based on Presidential Regulation of the Republic of Indonesia Number 29 of 2014. obliging each agency to be in charge of the implementation of its main tasks and functions in addition because the authority to manage resources supported a strategic objective plan determined by each agency. The media used for this accountability reporting is that the Office Performance Accountability Report (LAKIP) which is that the result of a process. The Government Agency Performance Accountability System (SAKIP) SAKIP is an instrument employed by government agencies to answer these obligations which consists of varied components that form one unit, namely strategic planning, performance measurement, performance reporting, and utilization of performance information.
The government in preparing a strategic plan must also concentrate to the applicable legal and regulatory bases.

AKIP is that the embodiment of the requirement of a government agency to account for the success and failure of the implementation of the organization's mission in achieving the goals and objectives that are set through a periodic accountability system (Dina, 2015) and (Martini, et al, 2019). Government performance accountability is usually highlighted because the accountability for the performance of state agencies doesn't match the expectations of the general public. There are still many local governments or government agencies during which the administration of state continues to be not in accordance with the established development plans (Martini, et al, 2020). The inconsistencies, one among which is that the accountability for governance through accountability for the performance of presidency agencies, are still not good and also the results of the assessment reviews don't seem to be followed up.

ToAKIP activity could be a sort of evaluation, namely assessing the extent of accountability or accountability for the results of the employment of the budget within the context of the belief of resultsoriented government. The evaluation of SAKIP refers to Government Regulation Number 8 of 2006 concerning 
Financial Reporting and Performance of Government Agencies and Presidential Regulation Number 29 of 2014 concerning SAKIP. Additionally, it refers to the RB Menpan Regulation Number 12 of 2015 concerning Guidelines for Evaluation of the Implementation of SAKIP.

This assessment shows the extent of effectiveness and efficiency of budget use compared to its performance achievements, the standard of the culture development of bureaucratic performance and resultsoriented governance within the Banyuasin Regency Government, which have shown good results, but not yet optimal. The components that are assessed include work planning, performance measurement, performance reporting, internal evaluation, and work performance.

Based on the results of the evaluation of the Banyuasin Regency Government, it's still not optimal to enchance the performance of Regional Government Organizations because there are several obstacles and problems faced by Regional Apparatus Organizations (OPD) which have a control on the delay in physical and financial realization within the third quarter in order that it's not reached $70 \%$ (https://bappedalitbang.banyuasinkab.go.id). In response to present, the government took the initiative and adjusted the monitoring pattern of development performance evaluation. Therefore it's necessary to boost the internal control system to help government agencies in changing monitoring patterns, and competent human resources are needed to be able to utilize technology and knowledge with the hope that the goal of improving government performance accountability is effective and efficient.

\section{LITERATURE REVIEW HYPOTHESIS DEVELOPMENT}

AND

Based on Presidential Regulation No. 29/2014, it's stated that "Accountability of government performance may be a manifestation of the requirement of a federal agency to be answerable for the success or failure of implementing the organization's mission in achieving the goals and objectives that are set through a periodic accountability system".The government control system in Indonesia is regulated in Government Regulation Number 60 of 2008 concerning the Govt Control System (SPIP) defines that the govt control system is an integral process of actions and activities disbursed continuously by the leadership and every one employees to supply adequate confidence for the achievement of organizational goals through effective and efficient activities, reliability of economic reporting, safeguarding state assets, and compliance with laws and regulations.

The mandatory use of data technology by the central government and native governments is regulated in Government Regulation Number 65 of 2010 which updates Government Regulation Number 56 of 2005 concerning Financial Information Systems, which states that the central and regional governments are obliged to develop and utilize technological advances to enchance the power to manage finances and distribute financial information to public services.Yendrawati (2013) states that human resource competence is that the ability of an individual in a company (institution) or a system to hold out their functions or authority to realize their goals effectively and efficiently. Competence is a capability to attain performance and to provide new outputs (outputs) and results obtained (outcomes). Supported the theoretical basis above, the researcher will develop a pursuit framework (Figure 1).

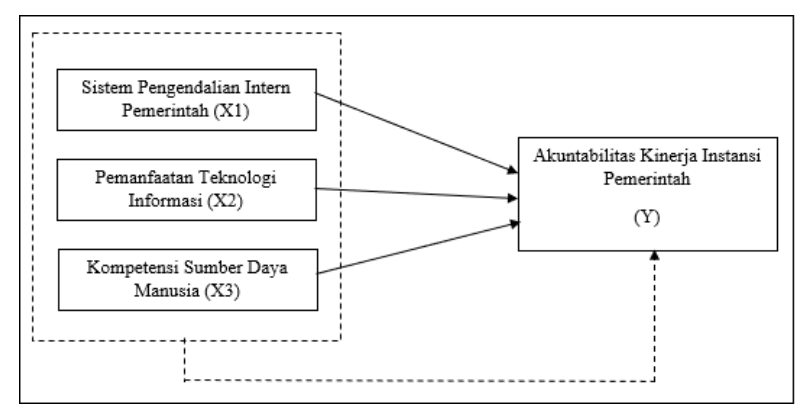

Source: Data processed, 2020

Figure 1. Research Hypothesis

\section{RESEARCH METHODOLOGY}

In this study, primary data was used with a quantitative approach. The sample selection technique used purposive sampling. The research sample consisted of 57 respondents who held the positions of head of service, secretary of service and Head of Subdivision. general and staffing within the regional apparatus organization of Banyuasin Regency. The data obtained were analyzed using descriptive analysis, instrument test, classical assumption test, multiple correlation analysis, coefficient of determination and hypothesis testing with the assistance of SPSS version 24 software..

\section{RESULT AND DISCUSSION}

\subsection{Result}

The results of the one sample Kolmogorov-Smirnov test show that the residual probability ( $p$ value) during this study features a value greater than 0.05 , which is adequate to 0.200 . This implies that the residual data is often distributed. The tolerance value for every variable is larger than 0.1 and also the VIF value is smaller than 10 in order that it is stated that there's no multicollinearity problem during this research model. Scatterplot images scatter don't form a pattern or random, therefore the regression during this study doesn't experience heteroscedasticity disorders. Or in other words the scatterplot doesn't form a specific pattern (spread). This means that there's no 
heteroscedasticity within the regression pattern in order that the regression model is possible to use.

Based on the results of multiple linear regression tests (Table 1), it can be seen that the multiple linear regression equation is as follows:

Performance Accountability of State Agencies = $2,987+0.221$ Government Control System + 0.232 Utilization of Knowledge Technology +0.654 Human Resource Competence + e.

Table 1. The Test Result of Multiple Linear Regression Analysis

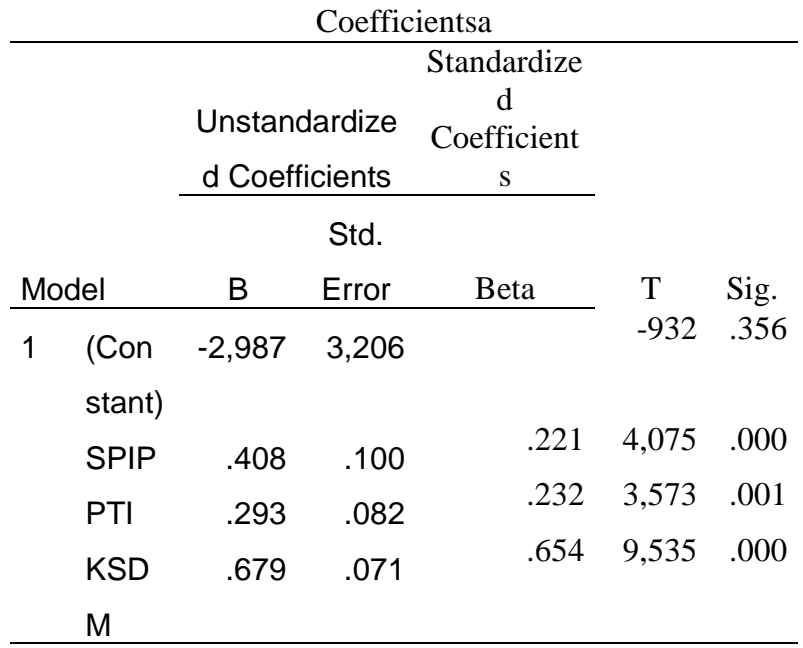

a. Dependent Variable: AKIP

Source: SPSS Output (2020)

The results of the partial significance test $(\mathrm{T}$ test), show The $t_{\text {count }}$ value of the government internal control system variable is equal to 4,075 with a major value of 0.000 . In other words, the worth of $t_{\text {count }}$ $(4,075)>t_{\text {table }}(2,006)$ and a significant value $(0.000)<$ 0.05 , so it will be concluded that partially the government control system variable includes a significant effect on the performance accountability state agencies with a positive effect. The t-count value of the data technology utilization variable is equal to 3,573 with abig value of 0.001 . In other words, the worth of $t_{\text {count }}(3,573)>t_{\text {table }}(2,006)$ and a big value $(0.001)<0.05$, so it may be concluded that partially the variable use of data technology encompasses a significant effect on the accountability of the performance of government state with a positive effect. The tcount value of the human resource competency variable is equal to 9,535 with a big value of 0.000 . In other words, the worth of $t_{\text {count }}(9,535)<t_{\text {table }}(2,006)$ and a big value is bigger $(0.000)>0.05$, so it's concluded that partially the human resource competency variable is critical towards the accountability of the performance of state agencies with a positive effect.

Simultaneous Significance Test (F test), yields F-count value (Table 1) of 117,056 and a significance of 0.000. This means that the F-count is equal to 117,056 greater than F-table 2.78, so it are often stated simultaneously that the Government Internal Control System, Utilization of data Technology and Human Resources Competence jointly affect the Performance Accountability of state Agencies.

Furthermore, the determination coefficient test $\left(\mathrm{R}^{2}\right)$, obtained the R Square value of 0.869 or $86.9 \%$, which suggests that there's a awfully close relationship between the variable quantity and therefore the dependent variable.

Table 3.The Test Results of Determination Coefficient (R2)

\begin{tabular}{|l|c|c|c|c|}
\multicolumn{5}{c|}{ Model Summary } \\
\begin{tabular}{|l|c|c|} 
Mo \\
del
\end{tabular} & $\mathrm{R}$ & $\begin{array}{c}\text { R } \\
\text { e }\end{array}$ & $\begin{array}{c}\text { Adjusted R } \\
\text { Square }\end{array}$ & $\begin{array}{c}\text { Std. Error of the } \\
\text { Estimate }\end{array}$ \\
\hline 1 & $.932 \mathrm{a}$ & .869 & .861 & 1,495 \\
\hline
\end{tabular}

a. Predictors: (Constant), KSDM, SPIP, PTI

Source: SPSS Output (2020)

\subsection{Discussion}

Partially it may be concluded that the govt internal control system incoporates a significant effect on the accountability of the performance of state agencies within the regional apparatus organization of Banyuasin Regency. This result's in line with Government Regulation Number 60 of 2008 concerning SPIP. The inner control system aims to supply sufficient confidence so as to attain effectiveness and efficiency within the achievement of state/regional government administration, reliability of ecconomic reporting, safeguarding state assets and compliance with laws and regulations.

Internal control (Martini, et al, 2019) has an influence on the performance accountability of state agencies because with continuous control over activities that are under the supervision of the leadership (internal). It'll create organizational goals that are appropriate, effective and efficient and have the potential to direct place of work towards achieving optimal performance (Martini, et al, 2020). The control disbursed, in order that the performance accountability that describes the achievement of targets also will increase. The internal system contains a positive and significant effect on the accountability of the performance of state agencies, meaning that the more implementation of the Inner Control System will increase the accountability of the performance of state agencies (Syahrir, et al, 2019, Soleman, et al, 2019, and Manulang, et al, 2017).

The use of data technology incorporates a significant effect on the performance accountability of state agencies within the regional apparatus organization of the Banyuasin Regency. This shows that the utilization of data technology within the sort of computers plays a crucial role and might assist 
government officials in managing overall agency documents. This computer is additonally used as a piece aid within the process of preparing local government financial reports.

The use of data technology incorporates a positive effect on the performance accountability of state agencies (Soleman, et al, 2019, and Chintya, 2015). Technology plays a vital role within the preparation of the Performance Accountability Report for State Agencies, which implies that the increased use of data technology will increase the accountability of the performance of government agencies.

Competence of human resource, partially includes a significant effect on the accountability of the performance of state agencies within the regional apparatus organization of Banyuasin Regency. This can be in line with Mubaraq (2017) and Trihapsoro (2015) who state that human resource competence contain a significant positive effect on the Performance Accountability of State Agencies. Human resource competencies greatly support the accountability of an OPD, meaning that the higher the competence of existing human resources, the more the accountability for the performance of government agencies will increase.

Based on the test results the coefficient of determination is $86.9 \%$, which indicates that the govt control system, the utilization of data technology and human resource competence, contains a simultaneous effect of $86.9 \%$ on the accountability of the performance of state agencies. While the remaining $13.1 \%$ is influenced by other factors not observed during this study.

\section{CONCLUSION}

The results showed that the govt control system, the utilization of information technology, and therefore the competence of human resources had a positive and significant effect on the performance accountability of state agencies.

The Banyuasin Regency Government can maintain and improve the government's control system, the utilization of data technology, and therefore the competence of human resources that are running well in order that the accountability of the performance of state agencies is recovering.

\section{ACKNOWLEDGMENTS}

The authors thankfully acknowledge scientific discussion with our colleagues from State Polytechnic of Sriwijaya, Indonesia. The authors would really like to acknowledge the anonymous reviewers at the 4th FIRST 2020 International Conference for their feedback on earlier version of the paper, and also thank to the two anonymous reviewers who provided feedback as a part of this proceeding review process.

\section{REFERENCES}

[1] Afrina, Dina. 2015. The Effect of the Implementation of authorizes Accounting Systems, Internal Control and Reporting Systems on Performance Accountability of State Agencies.

[2] Bappeda R \& D Banyuasin Regency https://bappeda-litbang.banyuasinkab.go.id/bupatidan-wakil-bupati-banyuasin-monitoring-capaikinerja-opd/

[3] Chintya, Irinie. 2015. The Effect of the Utilization of Data Technology and Control Systems on the Performance of State Agencies (Study on SKPD Kota Solok)

[3] Manullang, Surya Benediktus, Abdulla, Syukriy. 2017. Effect of Internal Control, Clarity of Objectives and Alter of Head of SKPD on performance accountability.

[4] Martini, Rita, Hartati, Sukmini, Zulkifli, \& Widyastuti, Endah. 2019. Sistem Pengendalian Intern Pemerintah atas Akuntabilitas Pengelolaan Keuangan Dana Desa di Kecamatan Sembawa. Jurnal Akademi Akuntansi, vol. 2, no. 1. doi: 10.22219/jaa.v2i1.8364.

[5] Martini, Rita, Agustin, Resy, \& Sari, K. R. 2020. Accrual Discretion Policy on Excess/Less Budget Financing at the Provincial Level. TEST Engineering \& Management, 82, 9925-9935.

[6] Martini, Rita, Sari, K. R., Somadi, T., \& Karman, I. W. 2019. "Financial Independence of the South Sumatra Regional Government" Proceedings of the International Conference On Applied Science and Technology 2019 - Social Sciences Track (iCASTSS 2019). 354, pp. 360-364. Denpasar: Atlantis Press. https://doi.org/10.2991/icastss19.2019.75

[7] Mubaraq, Husnul. 2017.The Influence of Compliance with Legislation, Utilization of Data Technology and Competence of Prsidency Officials on the Accountability of State Institutions Performance (Empirical Study of Regime Government Agencies in high hill cities)

[8] Republic of Indonesia. Government Regulation No. 65/2010 concerning Regional Financial Information Systems.

[9] Government Regulation Number 60 of 2008 concerning Government Internal Control System (SPIP). 
[10] __ Government Regulation Number 29 of 2014 concerning the Performance Accountability System of Presidnecy Agencies.

[11] Soleman, Risky, Soleman, Rusnan, Zainuddin. 2019. The Effect of Authorized Accounting Implementation, Internal Control System Quality and Data Technology Utilization on Accountability of Presidency Institutions Performance

[12] Syahrir, Muhammad, H. Hasbuddin, Hadisantoso, Erwin. 2019. The Influence of Organizational Culture, Control Systems, and Regional Financial Accounting Systems on the Performance Accountability of Presidency Agencies in Bombana Regency
[13] Trihapsoro, Argo. 2015. The Effect of Human Resource Quality, Utilization of Data Technology and Government Internal Control Systems on Local Government Performance (Study on Regional Work Units of Boyolali Regency). Muhammadiyah Surakarta university.

[14] Yendrawati, R. 2013. The Influence of Internal Control Systems and Human Resource Capacity on the Standard of Economic Statement Information with External Factors as Moderating Variables. JAAI, 17 (2), 166-175. 